\title{
Problems of Freshwater Biology
}

\section{A} SURVEY of certain aspects of freshwater biology was arranged by Sections D (Zoology) and $\mathrm{K}$ (Botany) of the British Association, under the chairmanship of Dr. E. S. Russell, at Aberdeen on September 10. One of the major problems con. sidered was that of the production of algæ in natural waters. These organisms serve as producers of organic materials, and hence their number is a measure of the amount of sub-aqueous life possible. They also serve as indicators of the quality of the water, a field which requires further investigation. On the other hand, their presence may lead to tastes or odours undesirable from a water consumer's point of view and, in waterworks, they may, if abundant, cause considerable expense in filtration.

Prof. F. E. Fritsch, in opening the symposium, pointed out that very little is really known about the way in which the phytoplankton of lakes and reservoirs pass through their periods of dormancy, or of the manner in which they are able to develop and to become abundant in the free floating condition. Few species are known to produce resting spores, and motile developmental stages appear to be infrequent. Prof. Fritsch summarised the existing information.

Dr. W. H. Pearsall then dealt with the relation between the abundance or scarcity of algæ and the chemical composition of the dissolved substances in the waters. He developed the view that the proportions between available nutritive substances, such as those yielding carbon, nitrogen and phosphorus, are of great importance both in determining algal abundance and also in deciding which species become predominant.
The examples quoted in these earlier papers sug. gest that freshwater biologists will soon require a further detailed knowledge both of the water movements in lakes and also of the manner in which nutritive substances are produced by the oxidation of organic matter in natural waters. Mr. J. T. Saunders approached one of these problems, that of water movements in lakes, by a rather novel method. Using a form of thermocouple, he has found it possible to measure water temperatures so rapidly as to throw considerable light on water movements. Among other details of interest was the conclusion that the oily patches common on the wind-swept surfaces of lakes are of lower temperature than the surrounding surface waters, and represent the upwelling of the return currents which balance the surface wind-drift.

Dr. B. Barnes approached the second problem, that of the sub-aqueous decay of organic matter, in summarising the available information about the biology of the aquatic fungi. Apparently these little-known organisms occur chiefly in shallow water and during periods of low temperature. Many of them are parasites and all appear to be of infrequent occurrence. Hence they may play only a small part in sub-aqueous organic decay, which is presumably to be attributed chiefly to bacteria.

Another major problem of aquatic biology, that of the food chains by which the larger animals are linked with the smaller organisms, was dealt with by Mr. F. K. Pentelow, who summarised extensive observations on the foods of fishes, particularly trout. His conclusion that trout have catholic tastes and are, on occasion, practically omnivorous, received abundant confirmation in the subsequent discussion.

\section{Building Trades Exhibition}

$\mathrm{T}$ is not so many years ago that building was one of the most traditional of our industries, it methods and materials having been handed down from generation to generation and being in many instances peculiar to their special localities. That this state of affairs no longer exists, and that the very varied assortment of trades now occupied in building have indeed 'put their house in order', is made evident by even the briefest of tours of the Building Trades Exhibition, which is being held at Olympia on September 12-26.

The immediate impression conveyed by the Exhibition is undoubtedly that of the high quality and specialised nature of the products exhibited. In some instances, as, for example, with electrical apparatus, it is fairly obvious that the products are the direct outcome of intensive research. In others, notably in the use of that apparently unsuitable material, aluminium foil, as a thermal insulator, established scientific prineiples have been successfully interpreted in a practical form.

Even with the older materials, such as bricks, paints and plasters, indications of scientific development are to be seen on every side. To appreciate this, it is only necessary to examine a stand such as that of Imperial Chemical Industries Ltd., where an extensive range of plasters and cement products is being shown, each suited to a special purpose and supplied ready mixed so that the minimum of time and skill is needed for application. The fact is also well illustrated by the number of materials which are now produced to detailed specifications.

The focus of scientific interest in the Exhibition lies, of course, in the comprehensive exhibit arranged by the Department of Scientific and Industrial Research, illustrating the work of the Building Research Station at Watford and of the Forest Products Research Laboratory at Princes Risborough. This ranges from fundamental work on the constitution of cements, to such varied problems as the behaviour of structural steelwork and reinforced concrete, the stability of paints on plastered surfaces, the designing of buildings to receive maximum sunshine, and the control of insect and fungoid pests in timber.

Perhaps the most interesting section of this exhibit is that dealing with the investigation of the causes of fracture of reinforced concrete piles during driving. Special piezo-electric gauges are embedded in the pile and are connected as required to a cathode ray oscillograph to give records of the impulsive and vibrational stresses caused by the blow. It has been found that tensile stresses of a dangerous order may be developed either at the head or the toe of the pile, according to the nature of the blow and the type of ground into which the pile is being driven. The 